\title{
The effect of cervical spinal cord stimulation on cervical spinal nerve root/brachial plexus injury
}

\author{
Servikal spinal kord stimülasyonunun servikal spinal sinir kökü/brakiyal pleksus \\ yaralanması üzerine etkisi
}

(D) Meltem KANAR, @ Gül KÖKNEL TALU, \ Halil ÇETiNGÖK

\begin{abstract}
Summary
Spinal cord stimulation (SCS) has been used for the treatment of chronic pain for almost 50 years. There have been several reports regarding to thoracic and lumbar SCS, while fewer publications have been documented for cervical SCS administration. In this article, we presented patient satisfaction after cervical SCS application in patients with chronic upper extremity pain. Three patients with cervical spinal nerve root or brachial plexus injury who reported no pain relief with the previous treatment modalities were identified. The patients were performed percutaneous cervical SCS. Cervical SCS implantation was successful in the first and the second patients, and with respect to decrease in VAS scores, analgesic drug requirements, and an increase in their quality of life, while the third patient had no pain relief. Cervical SCS may be an effective treatment option in upper extremity chronic pain syndromes as in the lower extremity pain syndromes treated with thoracolumbar SCS.
\end{abstract}

Keywords: Brachial plexus injury; cervical nerve root injury; chronic pain; neuromodulation; neuropathic pain; spinal cord stimulation.

\begin{abstract}
Özet
Spinal kord stimülasyonu (SKS), yaklaşık 50 yıldır kronik ağrı tedavisinde kullanılmaktadır. Torakal ve lomber SKS ile ilgili birçok yayın bildirilmiş iken, servikal SKS ile ilgili daha az yayına rastlanmaktadır. Bu yazımızda servikal SKS uygulamasının üç hastamızdaki sonuçlarını sunmayı amaçladık. Servikal spinal sinir veya brakiyal pleksus hasarı olan, diğer konservatif tedavi yöntemleri ile ağrı palyasyonu sağlanamayan üç hastaya perkütan servikal SKS implantasyonu uygulandı. Birinci ve ikinci hastada VAS skorlarında, ilaç gereksiniminde azalma, yaşam kalitesinde artış gözlenirken, üçüncü hastada yeterli ağrı palyasyonu gözlenmemiştir. Torakolomber SKS ile tedavi edilen alt ekstremite ağrı sendromlarında olduğu gibi, kronik üst ekstremite ağrısı olan hastalarda da servikal SKS'nin tedavi seçeneği olabileceği düşünülmektedir. Gelecekteki çalışmalar servikal SKS etkinliği ve uygulanabilirliği açısından yol gösterici olacaktır.
\end{abstract}

Anahtar sözcükler: Brakial pleksus hasarl; servikal sinir kökü hasarı; kronik ağrı; nöromodulasyon; nöropatik ağrl; spinal kord stimulasyonu.

\section{Introduction}

Spinal cord stimulation (SCS) was first performed by Shealy et al., ${ }^{[1]}$ in 1967, and it has been used for the treatment of chronic pain for almost 50 years. ${ }^{[2]}$ The technique became widespread in 1975 with the development of percutaneous electrodes. ${ }^{[2]}$ Modalities such as surgical ablative operations, pharmacotherapy, and physical therapy are applied in the treatment of chronic pain but may be insufficient. SCS produces neuromodulatory effect by stimulating spinal cord with low-intensity electrical impulses and can significantly change the perception of pain in patients with chronic pain. ${ }^{[3]}$ There have been several long-term and successful reports of thoracic and lumbar SCS, while fewer publications have been documented for cervical SCS administration. ${ }^{[4]}$ The aim of this case report is to evaluate and present patient satisfaction after cervical SCS application in patients with chronic upper extremity pain.

\section{Case Reports}

Case 1 - A 36-year-old male patient developed a C4 vertebral fracture and left carotid artery dissection as a result of a gunshot wound to the neck for 
four years ago before admitting to pain clinic. The patient complained of aching, throbbing, and neuropathic pain spreading to the left arm and neck. His visual analog scale (VAS) was 8-9/10. On physical examination, severe pain, coldness, weakness found on his left shoulder, arm, forearm and hand, and there was hypoesthesia on the left $\mathrm{C} 4, \mathrm{C} 5$, and C6 spinal nerve dermatome areas. Muscle strength on the left deltoid, triceps, flexor, and extensor digits was $4 / 5$. There was mild pain in the left leg, paresthesia in the right leg, temperature difference between the lower extremities, and he had impotence and urinary incontinence.

There were chronic, axonal degeneration involving the $\mathrm{C} 5$ and $\mathrm{C} 6$ spinal nerve roots, and left brachial plexus on electromyography. Cervical spinal magnetic resonance imaging (MRI) (2008) showed that C4-C5 facet segment fracture, left neural foramen obliteration, was present. He was prescribed pregabalin $300 \mathrm{mg} 2^{*} 1$ p.o, SSRI (sertraline) $50 \mathrm{mg}$ 1*1 p.o, baclofen $10 \mathrm{mg} \mathrm{1*2} \mathrm{p.o,} \mathrm{and} \mathrm{oxycodone}$ $10 \mathrm{mg} 4^{*} 1$ p.o before presented to clinic. He had a history of cervical epidural injection in an another clinic. However, he had no pain relief despite all the treatments.

In April 2013, a SCS catheter was inserted into the epidural space at the level of T2-T3 thoracic vertebra and fixed in the epidural space at the $\mathrm{C} 3-\mathrm{C} 4$ cervical vertebra level, with the percutaneous electrode slightly to the left of the midline (Fig. 1). He felt paresthesia on the painful area and reported $70 \%$ pain relief during trial period, and permanent SCS implantation was placed 4 weeks later. Patient's VAS score was 2-3/10 after permanent SCS implantation, and medical treatment was continued with pregabalin $300 \mathrm{mg} \mathrm{2*1}$ p.o and sertraline $50 \mathrm{mg} \mathrm{1*1}$ p.o. He reported no need for other analgesic drugs and improvement in his social life quality during long-term follow-up.

Case 2 - A 58-year-old male patient admitted with a history of causalgia such as severe burning pain in his left shoulder and arm associated with traumatic cervical root injury and left brachial plexus lesion due to dislodgement of a metal part from a working machine in 1978, at the age of 18 . His VAS score was $9 / 10$. On his physical examination, loss

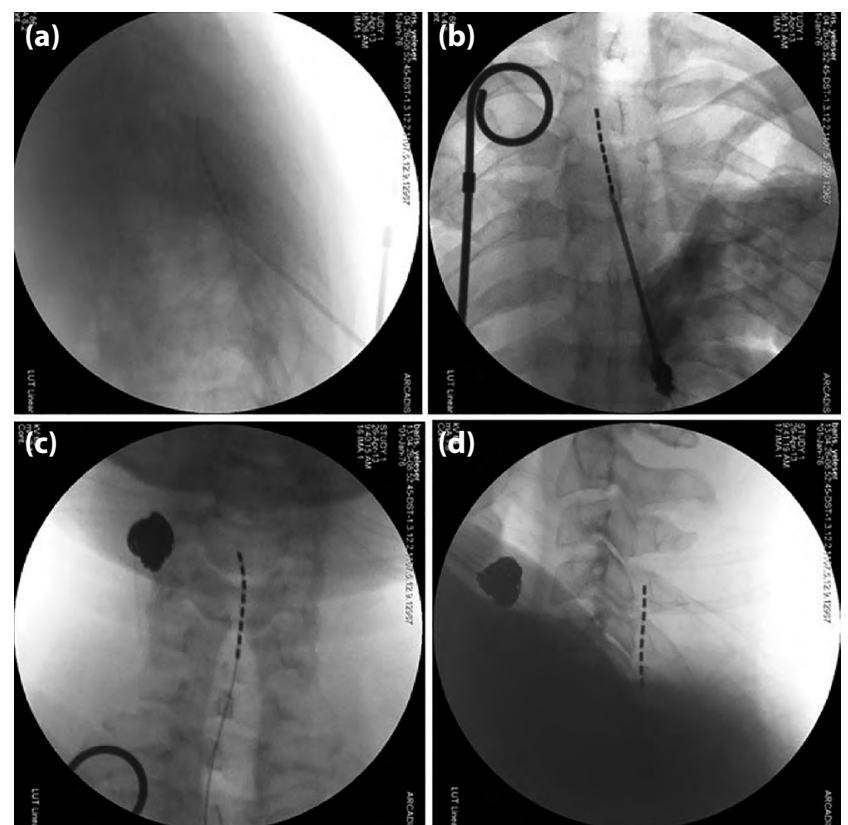

Figure 1. (a) Lateral image of leads placed through T2-3 intervertebral space, (entry site). (b) Anterior-posterior image of leads. (c) Anterior-posterior image of leads placed in the cervical C3-4 epidural space, (final position). (d) Lateral fluoroscopic image of leads placed in the cervical C3-4 epidural space and final position.

of sensation in the left elbow, muscular atrophy in the left arm, trophic changes in nails, dry skin, color changes, limitation of joint movements and severe pain, absence of deep tendon reflex, shoulder abductors, and biceps muscle strengths were $2 / 5$, deltoid, triceps, hand flexion-extension, and interosseous muscle strengths were $0 / 5$, and flask paralysis was present.

There was complete conduction defect in the left $n$. medianus, n. ulnaris, n. radialis, n. musculocutaneus, n. axillaris, and left brachial plexus lesion on electromyography, nerve root expansion was seen in and around the left neural foramen at the C7-T1 and T1T2 vertebral level in cervical computed tomography, and in myelography, complete nerve root avulsion at the vertebral levels of $\mathrm{C} 5-\mathrm{C} 6, \mathrm{C} 6-\mathrm{C} 7, \mathrm{C} 7-\mathrm{T} 1$, and partial nerve root avulsion at the vertebral level of $\mathrm{T} 1-$ T2 were observed. He was prescribed, fentanyl patch $100 \mathrm{mcq} / 48 \mathrm{~h}$ tts and gabapentin $600 \mathrm{mg} \mathrm{2*1/2}$ p.o. In Germany, in 1979, he was performed deep brain stimulation, but the patient had had no benefit from this treatment (MRI examination could not be performed due to this procedure.).

In 2004, SCS implantation was performed to the patient in our clinic whose pain was continued de- 

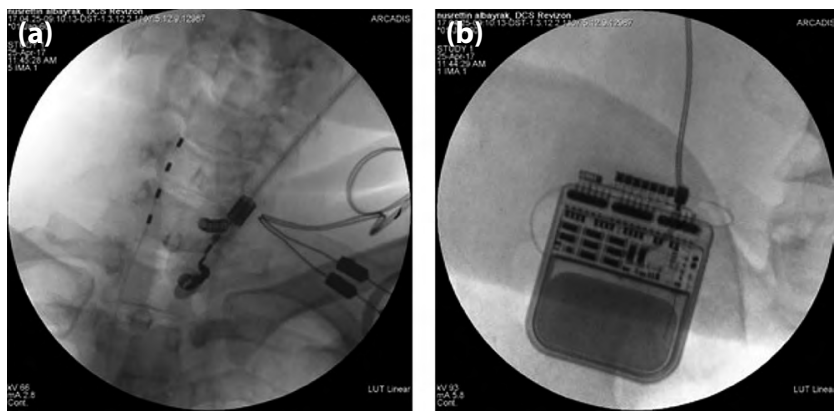

Figure 2. (a) Anterior-posterior fluoroscopic image of leads placed in the cervical C5-C6 left side of epidural space. (b) The implantable pulse generator used for management of the left upper extremity pain.

spite all the treatments. SCS catheter was inserted into the epidural space at the level of T2-T3 thoracic vertebrae and advanced to the $\mathrm{C} 5-\mathrm{C} 6$ cervical vertebra level and fixed in the same level of the epidural space (Fig. 2). The patient reported VAS score 2 after the procedure and satisfied with the procedure by $70 \%$. He received gabapentin 800 mg $2^{*} 1 / 2$ p.o as medical treatment only, and he reported increase in his quality of sleep and quality of life.

In 2009 and 2017, due to completion of the generators life time, neurostimulatory pulse generator revision was also performed.

Case 3 - A 46-year-old male patient was admitted with a complaint of the left shoulder, arm and hand pain with burning, tingling, and aching like pain after left brachial plexus injury due to traffic accident for 10 years ago.

Atrophic appearance was seen on his left shoulder, arm, and forearm and sensory and motor deficit were present on his physical examination. Transcutaneous electrical nerve stimulation was applied previously and gabapentin $600 \mathrm{mg} 3^{*} 1$ p.o, escitalopram (SSRI) $20 \mathrm{mg}^{*} 1$ p.o, and tramadol $100 \mathrm{mg} \mathrm{2*1}$ p.o were prescribed as the analgesic treatment.

The left stellate ganglion block was performed 3 times at the 1.5 year, 4.5 years, and 5.5 years after the brachial plexus injury. He had $40 \%$ pain relief from the first block but had no relief from subsequent procedures. Despite medical treatment and invasive procedures, it was decided to perform cervical SCS to the patient whose pain was ongoing as VAS 7/10.
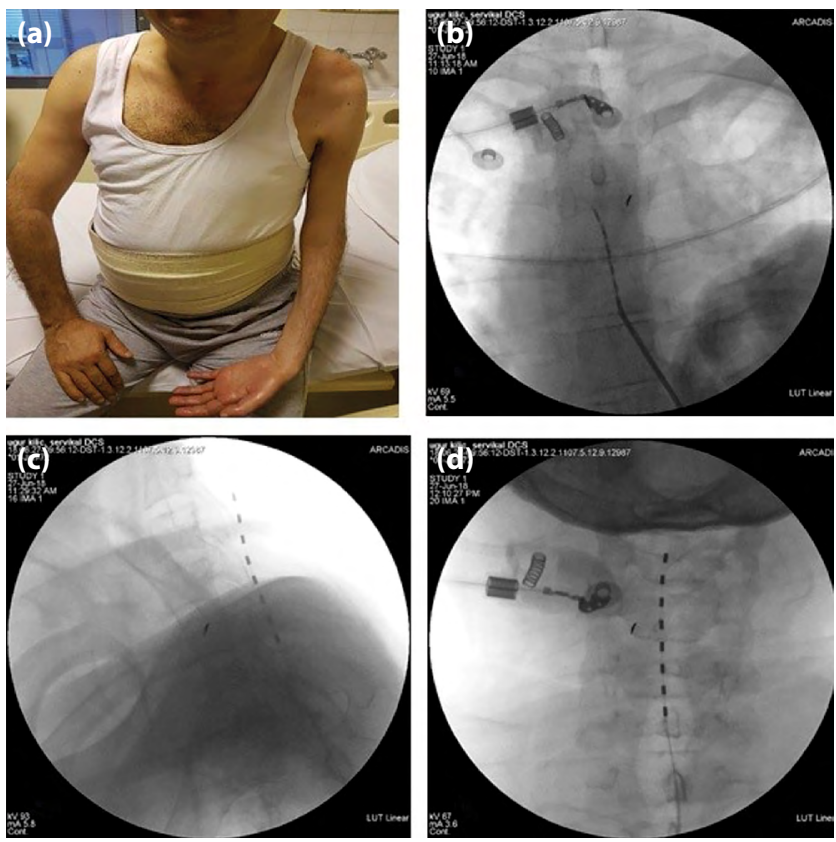

Figure 3. (a) The appearance of the patient's left upper extremity. (b) Anterior-posterior fluoroscopic image of leads placed in the thoracic T3-4 intervertebral epidural space, (entry site). (c) Lateral fluoroscopic image of leads placed in the thoracic T3-4 epidural space (entry site). (d) Anterior-posterior fluoroscopic image of leads placed in the cervical C4-C7 epidural space (final position).

EMG, in May 2018, lesion at the level of brachial plexus with the left cervical roots, involvement on proximal to dorsal root ganglion (DRG) (avulsion?), partial degeneration in upper and lower truncus, and complete axonal degeneration in peripheral nerves were present.

In cervicothoracic MRI, there were no other pathology other than protrusion and bulging in two levels of intervertebral disk. There was no pathology in dorsal spinal MRI and no contrast enhancement was observed.

In June 2018, SCS electrode was inserted into the epidural space at the level of T3-T4 thoracic vertebrae and fixed at the C4, 5, 6, and 7 (upper end of C7) cervical vertebra level of the epidural space (Fig. 3). During the cervical SCS trial period, the patient felt paresthesia in the painful area, but he reported $<50 \%$ pain relief. Different stimulation parameters applied for 3 weeks. Although the patient experienced paresthesia in painful areas during the trial period, SCS electrode was removed, due to less than $50 \%$ pain relief. The patient was discharged with medical treatment and recommendation of continuation of physical therapy. 


\section{Discussion}

SCS has become a preferred and increasingly widespread treatment modality in patients with chronic pain who have received various treatments previously. The basic theory of SCS is based on Melzack and Wall's "gate control theory," SCS-induced analgesia is multifactorial and has not yet been fully elucidated. ${ }^{[5]}$ Despite there are many studies and case series in thoracolumbar SCS implantation, the literature is limited in cervical SCS implantation. ${ }^{[6]}$ It is thought that the narrowness of the epidural space in the cervical region, the higher risk of cord compression, and hypermobility of the cervical spine may contribute to the limitation. ${ }^{[7]}$

In some respects, cervical SCS has some differences from the thoracolumbar SCS. First, the mobility of the cervical spine is higher and paresthesia changes are more likely to occur, but there is no large-scale study. Second, paresthesia of the trunk and lower extremities is possible due to the different anatomy of the dorsal column.$^{[8]}$ Vallejo et al., ${ }^{[9]}$ in a series of 5 patients, reported generalized paresthesia in three patients. However, since these patients have pain in the lower extremities, paresthesia is seen as an additional benefit rather than an undesirable condition. Similarly, lower extremity pain was present in the first one of our cases and our patient reported a decrease in lower extremity pain. The absence of lower extremity stimulation in all patients who were performed cervical SCS can be explained based on the study by Freirabend et al. ${ }^{[10]}$ In their study on dorsal column morphometry, they concluded that fiber density increased from medial to lateral. Thus, they stated that the lateral fibers will be affected in the low stimulation intensity and the stimulation will be detected in the upper extremity, and the high stimulation intensity will affect the medial fibers and the stimulation will be detected in the trunk and lower extremity.

In a prospective study of Deer et al., ${ }^{[11]}$ about the safety and efficacy of cervical SCS, they stated that the mean pain palliation of 38 patients was more than $50 \%(66.8 \%)$ in 1 year after SCS implantation. Hence, they proposed that cervical SCS is safe and effective. Similarly, in the study of Chivikula et al. ${ }^{[12]}$ in a large number of (121) patients, $75 \%$ of the cervical SCS electrode were implanted permanently and the patients' satisfaction rate was $72.4 \%$. The rate of pain pallation was $58.7 \%$ about the cervical SCS implantation, such as thoracic and lumbar areas. Kumar et al. ${ }^{[13]}$ evaluated ten patients who were performed cervical SCS implantation, by the VAS, Oswelt disability index (ODI) and Beck depression inventory (BDI) of the patients. They observed a significant improvement in VAS scores of $34 \%$, 9.2\% for ODI scores, and $29.6 \%$ for BDI scores for the long-term follow-up for about 7 years. Moreover, it is thought that the early application of SCS, including cervical SCS, in long-term chronic pain treatment will be more beneficial.

In addition, Garg A. and Danesh H. ${ }^{[14]}$ reported a case of cervical DRG neuromodulation in a patient with complex regional pain syndrome who was previously performed cervical discectomy. During the procedure, they reported that the patient had scar tissue in the posterior epidural area due to the cervical discectomy operation previously, and incidentally, the lead tip was directed to the C6 foramen, so they fixed the electrode at the level of the C6 DRG. They reported $70 \%$ pain relief and stated that especially in distal extremity pain, stimulation of DRG may be an alternative treatment to SCS.

In our cases, cervical SCS implantation provided pain relief in the first and the second patients and an increase in their quality of life. The well-being of the second case has been going on for about 40 years and the termination of the intensive opioid requirement is considered highly valuable. Third patient had $<50 \%$ pain relief and permanent implantation was not performed. Pain characteristics were similar in all three patients. The third patient's inability to benefit from the procedure could not be attributed to the duration of pain because the duration of pain was quite different in all three patients, and 4, 40 and 10 years, respectively. However, the painful area, that including the neck, shoulder, arm, forearm, and hand was quite wide, and the absence of muscle strength in these areas $(0 / 5)$, lack of sensitivity in any way, absence of intact myelinated A-beta fibers, and degeneration of the dorsal column fibers by the lesion in the proximal nerve roots, which is very close to the dorsal root ganglia, may have contributed to absence of pain relief. ${ }^{[15]}$ 
Interventional neuromodulation methods are becoming increasingly widespread in chronic pain. SCS has some advantages such as reducing the need for oral analgesics that have many side effects, reducing recurrent invasive procedures such as sympathetic nerve blocks, programmable electrical stimulation according to patient pain, and being reversible. At present, there are randomized controlled trials of thoracic and lumbar SCS. However, cervical SCS may also be an effective treatment option in the upper extremity chronic pain syndromes. Further prospective, randomized, controlled studies will guide the effectiveness, and applicability of cervical SCS in the future.

Informed Consent: Written informed consent was obtained from the patient for the publication of the case report and the accompanying images.

\section{Conflict-of-interest issues regarding the authorship or article: None declared.}

\section{Peer-rewiew: Externally peer-reviewed.}

\section{References}

1. Shealy CN, Mortimer JT, Reswick JB. Electrical inhibition of pain by stimulation of the dorsal columns: Preliminary clinical report. Anesth Analg 1967;46:489-91. [CrossRef]

2. Erdine S. Algolojide girişimsel yöntemler. Istanbul: Nobel Medical Publishers; 2012. p. 511.

3. Manca A, Kumar K, Taylor RS, Jacques L, Eldabe S, Meglio M, et al. Quality of life, resource consumption and costs of spinal cord stimulation versus conventional medical management in neuropathic pain patients with failed back surgery syndrome (PROCESS trial). Eur J Pain 2008;12:1047-58.

4. Tomycz ND, Deibert CP, Moossy JJ. Cervicomedullary junction spinal cord stimulation for head and facial pain. Headache 2011;51:418-25. [CrossRef]
5. Caylor J, Reddy R, Yin S, Cui C, Huang M, Huang C, et al. Spinal cord stimulation in chronic pain: Evidence and theory for mechanisms of action. Bioelectron Med 2019;5:12.

6. Costantini A, Buchser E, Van Buyten JP. Spinal cord stimulation for the treatment of chronic pain in patients with lumbar spinal stenosis. Neuromodulation 2010;13:27580. [CrossRef]

7. Soldati E. National Italian register of implantable systems for spinal cord stimulation (SCS): Analysis of preliminary data. Neuromodulation 2002;5:7-15. [CrossRef]

8. Wolter T, Kieselbach K. Cervical spinal cord stimulation: An analysis of 23 patients with long-term follow-up. Pain Physician 2012;15:203-12. [CrossRef]

9. Vallejo R, Kramer J, Benyamin R. Neuromodulation of the cervical spinal cord in the treatment of chronic intractable neck and upper extremity pain: A case series and review of the literature. Pain Physician 2007;10:305-11. [CrossRef]

10. Feirabend HK, Choufoer H, Ploeger S, Holsheimer J, van Gool JD. Morphometry of human superficial dorsal and dorsolateral column fibres: Significance to spinal cord stimulation. Brain 2002;125:1137-49. [CrossRef]

11. Deer TR, Skaribas IM, Haider N, Salmon J, Kim C, Nelson $C$, et al. Effectiveness of cervical spinal cord stimulation for the management of chronic pain. Neuromodulation 2014;17:265-71. [CrossRef]

12. Chivukula S, Tempel ZJ, Weiner GM, Gande AV, Chen CJ, Ding $D$, et al. Cervical and cervicomedullary spinal cord stimulation for chronic pain: Efficacy and outcomes. Clin Neurol Neurosurg 2014;127:33-41. [CrossRef]

13. Kumar K, Rizvi S, Bnurs SB. Spinal cord stimulation is effective in management of complex regional pain syndrome I: Fact or fiction. Neurosurgery 2011;69:566-80. [CrossRef]

14. Garg A, Danesh H. Neuromodulation of the cervical dorsal root ganglion for upper extremity complex regional pain syndrome-case report. Neuromodulation 2015;18:765-8.

15. Brill S, Aryeh IG. Neuromodulation in the management of pain from brachial plexus injury. Pain Physician 2008;11:81-5. [CrossRef] 